\title{
Investigating municipal wastewater treatment in the sultanate of Oman
}

\author{
M. S. Baawain, A. M. Al-Futaisi, A. Al-Omairi \& M. Al-Jabri \\ Department of Civil and Architectural Engineering, \\ Sultan Qaboos University, Oman
}

\begin{abstract}
Municipal wastewater is the water generated from domestic, commercial, and public sources. This water can be viewed as the only potential water source that will increase as population grows. The importance of wastewater as a potential source of water is apparent in countries that suffer from shortage of water. However, it must be treated properly before reuse and/or disposal due to the need for controlling many parameters such as biochemical oxygen demand (BOD), chemical oxygen demand (COD), solids, heavy metals, anions and microbial content. The aim of this study is to investigate municipal wastewater treatment in the Sultanate of Oman by analyzing wastewater samples collected from different treatment plants in three regions of the country (Muscat, Salalah, and Sohar). Comprehensive analyses including physical, chemical and biological characterization of raw wastewater and final effluents were conducted by collecting samples from major treatment units within the studied treatment plants. Consequently, comprehensive database was established for the raw municipal wastewater quality in the three regions and the performance of the treatment plants over 12 months. The levels of constituents in the final effluents from the treatment plants in the three regions were compared with Omani standards to evaluate their suitability for the current (e.g. landscape irrigation and groundwater recharge) and/or alternative (e.g. cooling and processing water) applications. Better aeration, oxidation, adsorption and disinfection technologies were recommended to improve the quality some of studied treatment plants final effluents.
\end{abstract}

Keywords: wastewater, Oman, chemical characterization, physical and biological characterization. 


\section{Introduction}

Wastewaters, generated from domestic, commercial, industrial and agricultural sources, can be viewed as the only potential water source that will increase as the population grows [1]. The quality of wastewaters depends on their source, which can be domestic, commercial, industrial and/or agricultural. Hence, raw wastewater often contains significant concentrations of microorganisms, nutrients, and heavy metals [2]. Therefore, such wastewaters have to be treated to remove/reduce their impurities for safe discharge and/or reuse purposes.

The concept of reusing wastewater is becoming widely accepted and adopted by many countries especially those experiencing water shortages $[2,3]$. Reusing treated wastewater effluents can significantly reduce or completely remove the impact of these effluents on receiving environments. Additionally, the reuse of wastewaters may reduce the amount of water that needs to be extracted from environmental water sources. However, due to health and safety concerns, water reuse applications are mostly restricted to non-potable uses such as landscape and agricultural irrigation [4]. Furthermore, the reuse of the wastewater is associated with concerns regarding potential microbial (e.g. Cyanobacteria; microorganisms that can cause severe health problems in livestock and human population, including liver damages, neurological disorders, and liver cancers [5-7]) and chemical (e.g. endocrine disrupting compounds (EDCs); a wide group of environmental pollutants that are able to disrupt synthesis and metabolism of endogenous hormones and hormone receptors [8-10]) contamination of water sources and consequently water supplies.

In Oman, wastewaters collected from domestic and commercial areas are transferred to either wastewater treatment plants (WWTPs) or lagoons via sewer systems (very few) or through tankers from septic tanks (majority). For example, there are collection and treatment systems for about $25 \%$ of Muscat municipal population [11]. Wastewaters effluents exiting the WWTPs have been used for landscape irrigation and recharging ground water to resist salt water intrusion in coastal areas.

Recent study on groundwater quality near Muscat area (Barka catchment) indicated elevated concentrations of inorganic constituents, chemical oxygen demand (COD), biochemical oxygen demand (BOD) and bacteria [12]. Another study conducted by [13] showed high levels of lead and chromium in samples taken from private wells in Batina area, which were attributed to uncontrolled industrial discharges. Water quality tests obtained from recharge wells in Salalah indicated the existence of elevated organic and microbial contamination [14].

This study aims at evaluating the current situation of wastewater treatment in Muscat, Sohar and Salalah areas. The study involves extensive wastewater sampling from treatment units. The analysis involves physical, chemical and biological characterization of the collected samples. Results shown in this paper covered six wastewater plants from January 2009 to December 2009. 


\section{Study area}

This paper tries to characterize wastewater treatment in three regions in Oman (Muscat, Salalah and Sohar). Furthermore, the study describes six domestic treatment plants in the studied regions (three in Muscat, two in Salalah, and one in Sohar). Table 1 summarizes the flow rates entering the five plants and the applications of the treated effluents.

The choice of the three regions is basically due to the geographical location, final effluent application, industrial practices and sewer collection in each region. For example, Darsait sewage treatment plant (STP) receives its wastewater $\left(21000 \mathrm{~m}^{3} / \mathrm{d}\right)$ through sewer network while Alansab STP receives its influents $\left(25000 \mathrm{~m}^{3} / \mathrm{d}\right)$ through tankers. Similarly, Salalah STP receives its $22000 \mathrm{~m}^{3} / \mathrm{d}$ wastewater through sewer network while Salalah Oxidation Pond receives its $3000 \mathrm{~m}^{3} / \mathrm{d}$ wastewater through tankers. Sohar STP receives its raw wastewater $\left(6600 \mathrm{~m}^{3} / \mathrm{d}\right)$ through both sewer network and tankers. Both treated wastewater in Muscat and Sohar are used for landscape irrigation. However, Sohar is undergoing industrial development that worth investigating the quality of treated effluents. On the other hand, treated effluents from Salalah STP are used for groundwater recharge while effluents from the oxidation ponds are discharged to adjacent valley until now.

Table 1: $\quad$ Basic information about the studied wastewater treatment plants.

\begin{tabular}{|c|c|c|}
\hline Treatment Plant & Flowrate, $\mathrm{m}^{3} / \mathrm{d}$ & $\begin{array}{c}\text { Application of Treated } \\
\text { Effluents }\end{array}$ \\
\hline Darsait STP & 21000 & Landscaping \\
\hline Alansab STP & 25000 & Landscaping \\
\hline Rusail STP & 300 & Landscaping \\
\hline Sohar STP & 6600 & Landscaping \\
\hline Salalah STP & 22000 & Groundwater recharge \\
\hline Salalah Oxidation Ponds & 3000 & Valley discharge \\
\hline
\end{tabular}

\section{Characterization results}

\section{$3.1 \mathrm{pH}$ and EC}

Results obtained for average $\mathrm{pH}$ and EC over the study period are shown in Table 2. The average $\mathrm{pH}$ values for raw wastewater of the studied treatment plants ranged from 6 to 7.5. The treated effluents $\mathrm{pH}$ values for all treatment plants meet the Omani standards range which is 6 to 9 . On the other hand, the average EC of the raw sewage ranged from 1000 to $2500 \mu \mathrm{S} / \mathrm{cm}$. Furthermore, the average EC of the treated effluents for Darsait STP, Alansab STP, Rusail STP, Salalah STP, and Sohar STP are within the Omani Standards 1 (2000 $\mu \mathrm{S} / \mathrm{cm}$ while the average EC value obtained for Salalah Oxidation Pond is with Omani Standards $2(2700 \mu \mathrm{S} / \mathrm{cm})$. 
Table 2: $\quad$ Summary of $\mathrm{pH}$ and $\mathrm{EC}$ results for the studied treatment plants.

\begin{tabular}{|c|c|c|c|c|c|c|}
\hline & $\begin{array}{c}\text { Darsait } \\
\text { STP }\end{array}$ & $\begin{array}{c}\text { Alansab } \\
\text { STP }\end{array}$ & $\begin{array}{c}\text { Rusail } \\
\text { STP }\end{array}$ & $\begin{array}{c}\text { Salalah } \\
\text { STP }\end{array}$ & $\begin{array}{c}\text { Salalah } \\
\text { Oxidation } \\
\text { Pond }\end{array}$ & $\begin{array}{c}\text { Sohar } \\
\text { STP }\end{array}$ \\
\hline Raw sewage & & & & & & \\
\hline $\mathrm{pH}$ & 6.70 & 6.58 & 6.32 & 6.87 & 7.03 & 6.72 \\
\hline $\mathrm{EC}(\mu \mathrm{S} / \mathrm{cm})$ & 1121 & 1518 & 1073 & 2153 & 2785 & 1552 \\
\hline Final effluent & & & & & & \\
\hline $\mathrm{pH}$ & 7.15 & 7.26 & 7.07 & 7.40 & 7.46 & 7.21 \\
\hline $\mathrm{EC}(\mu \mathrm{S} / \mathrm{cm})$ & 1010 & 1628 & 950 & 1830 & 2605 & 1336 \\
\hline
\end{tabular}

\subsection{Solids}

Table 3 summarizes the results obtained for total suspended solids (TSS) and total dissolved solids (TDS) for the studied treatment plants. Results showed that the average TSS for untreated wastewater ranged from 100 to about $700 \mathrm{mg} / \mathrm{L}$ while the average TDS values for raw sewage ranged from 600 to about $1200 \mathrm{mg} / \mathrm{L}$.

The average TSS results of treated effluents showed that effluents from both Sohar STP and Salalah STP are with Omani Standards $1(15 \mathrm{mg} / \mathrm{L})$ while TSS results of Darsait STP, Alansab STP and Rusail STP effluents are within Omani Standards $2(30 \mathrm{mg} / \mathrm{L})$. However, the obtained TSS value of effluents from Salalah Oxidation Pond is outside the two Omani standards. On the other hand, final effluent results of TDS from all treatment plants are within Oman Standards 1 and 2 (1500 and $2000 \mathrm{mg} / \mathrm{L}$, respectively).

Table 3: $\quad$ Summary of solid results (in $\mathrm{mg} / \mathrm{L}$ ) for the studied treatment plants.

\begin{tabular}{|c|c|c|c|c|c|c|}
\hline & $\begin{array}{c}\text { Darsait } \\
\text { STP }\end{array}$ & $\begin{array}{c}\text { Alansab } \\
\text { STP }\end{array}$ & $\begin{array}{c}\text { Rusail } \\
\text { STP }\end{array}$ & $\begin{array}{c}\text { Salalah } \\
\text { STP }\end{array}$ & $\begin{array}{c}\text { Salalah } \\
\text { Oxidation } \\
\text { Pond }\end{array}$ & $\begin{array}{c}\text { Sohar } \\
\text { STP }\end{array}$ \\
\hline TSS & & & & & & \\
\hline Raw sewage & 225 & 482 & 106 & 407 & 666 & 198 \\
\hline Final effluent & 17 & 28 & 16 & 11 & 64 & 13 \\
\hline TDS & & & & & & \\
\hline Raw sewage & 602 & 620 & 600 & 1194 & 1610 & 893 \\
\hline Final effluent & 621 & 673 & 594 & 1099 & 1490 & 778 \\
\hline
\end{tabular}

\subsection{BOD and COD}

Table 4 shows a summary of $\mathrm{BOD}_{5}$ and COD results for the studied treatment plants. It can be seen that the average $\mathrm{BOD}_{5}$ for the untreated wastewater of the treatment plants ranged from 176 to $304 \mathrm{mg} / \mathrm{L}$. The average COD results for raw sewage ranged from 320 to $973 \mathrm{mg} / \mathrm{L}$ for all treatment plants. 
Table 4: Summary of $\mathrm{BOD}_{5}$ and $\mathrm{COD}$ results for the studied treatment plants.

\begin{tabular}{|c|c|c|c|c|c|c|}
\hline & $\begin{array}{c}\text { Darsait } \\
\text { STP }\end{array}$ & $\begin{array}{c}\text { Alansab } \\
\text { STP }\end{array}$ & $\begin{array}{c}\text { Rusail } \\
\text { STP }\end{array}$ & $\begin{array}{c}\text { Salalah } \\
\text { STP }\end{array}$ & $\begin{array}{c}\text { Salalah } \\
\text { Oxidation } \\
\text { Pond }\end{array}$ & $\begin{array}{c}\text { Sohar } \\
\text { STP }\end{array}$ \\
\hline $\begin{array}{c}\text { Raw } \\
\text { sewage }\end{array}$ & 195 & 176 & 187 & 219 & 207 & 304 \\
\hline $\begin{array}{c}\text { BOD } \\
(\mathrm{mg} / \mathrm{L})\end{array}$ & 579 & 574 & 407 & 692 & 973 & 320 \\
\hline $\begin{array}{c}\text { COD } \\
(\mathrm{mg} / \mathrm{L})\end{array}$ & 1 & 1 & 3 & 3 & 6 & 3 \\
\hline $\begin{array}{c}\text { Final } \\
\text { effluent }\end{array}$ & 6 & 28 & 10 & 2 & - & 54 \\
\hline $\begin{array}{c}\text { BOD } \\
(\mathrm{mg} / \mathrm{L})\end{array}$ & & & & & & \\
\hline $\begin{array}{c}\mathrm{COD} \\
(\mathrm{mg} / \mathrm{L})\end{array}$ & & & & & & \\
\hline
\end{tabular}

According to the obtained results, effluents from the six plants were will with the Omani Standards in regards with BOD values $(15 \mathrm{mg} / \mathrm{L}$ (Standards 1) and $20 \mathrm{mg} / \mathrm{L}$ (Standards 2)). Similarly, COD values were within the Omani standards for all plants (150 mg/L (Standards 1) and $200 \mathrm{mg} / \mathrm{L}$ (Standards 2)).

\subsection{Cations}

Table 5 illustrates a summary of major cations results for the studied treatment plants. The average values of most of the heavy metals in the final effluents were within the Omani Standards. However, some concern can be raised about the average values of Mo in the final effluents as all plants exceeded Omani Standards 1 for treated wastewater. Furthermore, Alansab STP and Salalah Oxidation Pond violated both Oman Standards 1 and 2.

\subsection{Anions}

A summary of major anions results for the studied treatment plants is shown in Table 6. The values of most of the anions in the effluents were within the Omani Standards. However, some concern can be raised about the average values of nitrate $\left(\mathrm{NO}_{3}\right)$ as they exceeded Omani Standards for treated effluents $(50 \mathrm{mg} / \mathrm{L})$. This increase in $\mathrm{NO}_{3}$ in the final effluent can be related to the oxidation of ammonia in the aeration tank (see next section). Furthermore, all treatment plants except Salalah STP violated Omani Standards for sulphate $\left(\mathrm{SO}_{4}\right)$ concentration in the final effluents $(40 \mathrm{mg} / \mathrm{L})$. It should be noted that no Omani Standards are set for bromide, nitrates, and nitrite in final effluents. 
Table 5: $\quad$ Summary of major cations results (in $\mathrm{mg} / \mathrm{L}$ ) for the studied plants.

\begin{tabular}{|c|c|c|c|c|c|c|c|}
\hline & $\mathrm{Cu}$ & $\mathrm{Zn}$ & $\mathrm{Ni}$ & $\mathrm{Co}$ & $\mathrm{Mo}$ & $\mathrm{Pb}$ & $\mathrm{Al}$ \\
\hline Darsait STP & & & & & & & \\
\hline Raw sewage & 0.029 & 1.697 & 0.016 & 0.097 & 0.014 & 0.030 & 0.404 \\
\hline Final effluent & 0.015 & 0.040 & 0.042 & 0.020 & 0.017 & 0.012 & 0.173 \\
\hline Alansab STP & & & & & & & \\
\hline Raw sewage & 0.009 & 0.012 & 0.007 & 0.020 & 0.017 & 0.082 & 0.064 \\
\hline Final effluent & 0.011 & 0.020 & 0.007 & 0.020 & 0.063 & 0.017 & 0.026 \\
\hline Rusail STP & & & & & & & \\
\hline Raw sewage & 0.016 & 0.011 & 0.012 & 0.201 & 0.044 & 0.060 & 0.065 \\
\hline Final effluent & 0.004 & 0.021 & 0.011 & 0.011 & 0.024 & 0.027 & 0.059 \\
\hline Salalah STP & & & & & & & \\
\hline Raw sewage & 0.008 & 0.022 & 0.011 & 0.020 & 0.033 & 0.047 & 0.019 \\
\hline Final effluent & 0.008 & 0.022 & 0.011 & 0.013 & 0.043 & 0.037 & 0.007 \\
\hline Salalah OP & & & & & & & \\
\hline Raw sewage & 0.013 & 0.033 & 0.014 & 0.020 & 0.037 & 0.043 & 0.379 \\
\hline Final effluent & 0.010 & 0.005 & 0.020 & 0.020 & 0.068 & 0.032 & 0.019 \\
\hline $\begin{array}{c}\text { Omani } \\
\text { Standards }\end{array}$ & & & & & & & \\
\hline 1 & 0.5 & 5 & 0.1 & 0.05 & 0.01 & 0.1 & 5 \\
\hline 2 & 1 & 5 & 0.1 & 0.05 & 0.05 & 0.2 & 5 \\
\hline
\end{tabular}

\subsection{Ammonia}

Table 7 demonstrates a summary of ammonia results for the studied treatment plants. The average ammonia concentration in raw wastewater ranged from 40 $\mathrm{mg} / \mathrm{L}$ in Rusail STP to $173 \mathrm{mg} / \mathrm{L}$ in Salalah Oxidation Pond.

The average values of ammonia in the final effluents ranged from $0.5 \mathrm{mg} / \mathrm{L}$ in Sohar STP to $21.5 \mathrm{mg} / \mathrm{L}$ in Salalah Oxidation Pond. This reduction can be explained by the oxidation of initial ammonia concentration to nitrite and nitrate. Furthermore, the average ammonia levels in most of the treated plants except Salalah and Sohar STPs were beyond the Omani Standards for final effluents (5 to $10 \mathrm{mg} / \mathrm{L})$.

\subsection{Biological parameters}

Microbiological tests for total coliform and E-coli (part of fecal coliform) bacteria (most probable number, MPN) were conducted on final effluents as shown in Table 8. Obtained results revealed that treated effluent from Rusail STP exceeded Omani Standards 1 and 2 (200 and 1000 MPN, respectively for fecal coliform). Furthermore, Alansab STP, Salalah Oxidation Pond and Sohar STP exceeded Omani Standards 1 (200 MPN for fecal coliform). Only Darsait and Salalah STPs final effluents are within both Omani Standards limits. 
Table 6: $\quad$ Summary of major anions results (in $\mathrm{mg} / \mathrm{L}$ ) for the studied plants.

\begin{tabular}{|c|c|c|c|c|c|c|c|}
\hline & $\mathrm{F}$ & $\mathrm{Cl}$ & $\mathrm{Br}$ & $\mathrm{NO}_{3}$ & $\mathrm{PO}_{4}$ & $\mathrm{SO}_{4}$ & $\mathrm{NO}_{2}$ \\
\hline Darsait STP & & & & & & & \\
\hline Raw sewage & 0.22 & 154 & 2.46 & 9.67 & 12.5 & 42.0 & 0.32 \\
\hline Final Effluent & 0.15 & 159 & 0.400 & 32.6 & 2.52 & 55.4 & 0.45 \\
\hline Alansab STP & & & & & & & \\
\hline Raw sewage & 0.25 & 188 & 3.15 & 7.19 & 6.81 & 15.9 & 0.38 \\
\hline Final Effluent & 0.23 & 287 & 3.99 & 65.4 & 2.99 & 62.7 & 0.17 \\
\hline Rusail STP & & & & & & & \\
\hline Raw sewage & 0.38 & 96.8 & 1.32 & 30.7 & 9.51 & 34.8 & 0.06 \\
\hline Final Effluent & 0.41 & 87.5 & 2.95 & 25.7 & 5.61 & 56.5 & 0.88 \\
\hline Salalah STP & & & & & & & \\
\hline Raw sewage & 0.14 & 285 & 4.21 & 23.9 & 13.1 & 11.1 & 0.29 \\
\hline Final Effluent & 0.17 & 300 & 3.44 & 46.6 & 4.57 & 60.8 & 0.09 \\
\hline Salalah OP & & & & & & & \\
\hline Raw sewage & 0.19 & 498 & 6.05 & 9.56 & 6.30 & 17.9 & 1.00 \\
\hline Final Effluent & 0.01 & 108 & 24.05 & 6.88 & 0.38 & 12.2 & 1.14 \\
\hline Sohar STP & & & & & & & \\
\hline Raw sewage & 0.18 & 182 & 4.17 & 26.1 & 8.22 & 37.4 & 0.14 \\
\hline Final Effluent & 0.19 & 259 & 3.73 & 65.6 & 7.28 & 95.4 & 0.15 \\
\hline Standards & & & & & & & \\
\hline 1 & 1 & 650 & NA & 50 & NA & 40 & NA \\
\hline 2 & 2 & 650 & NA & 50 & NA & 40 & NA \\
\hline & & & & & \\
\hline
\end{tabular}

Table 7: $\quad$ Summary of ammonia results (in $\mathrm{mg} / \mathrm{L}$ ) for the studied plants.

\begin{tabular}{|c|c|c|c|c|c|c|}
\hline & $\begin{array}{c}\text { Darsait } \\
\text { STP }\end{array}$ & $\begin{array}{c}\text { Alansab } \\
\text { STP }\end{array}$ & $\begin{array}{c}\text { Rusail } \\
\text { STP }\end{array}$ & $\begin{array}{c}\text { Salalah } \\
\text { STP }\end{array}$ & $\begin{array}{c}\text { Salalah } \\
\text { Oxidation } \\
\text { Pond }\end{array}$ & $\begin{array}{c}\text { Sohar } \\
\text { STP }\end{array}$ \\
\hline Raw Sewage & 86.3 & 121 & 40 & 122 & 173 & 97.5 \\
\hline $\begin{array}{c}\text { Final } \\
\text { Effluent }\end{array}$ & 11.1 & 15.3 & 11.8 & 3.00 & 21.5 & 0.53 \\
\hline
\end{tabular}


Table 8: Summary of microbiology results (in MPN) for the treatment plants.

\begin{tabular}{|c|c|c|c|c|c|c|}
\hline & $\begin{array}{c}\text { Darsait } \\
\text { STP }\end{array}$ & $\begin{array}{c}\text { Alansab } \\
\text { STP }\end{array}$ & $\begin{array}{c}\text { Rusail } \\
\text { STP }\end{array}$ & $\begin{array}{c}\text { Salalah } \\
\text { STP }\end{array}$ & $\begin{array}{c}\text { Salalah } \\
\text { OP }\end{array}$ & $\begin{array}{c}\text { Sohar } \\
\text { STP }\end{array}$ \\
\hline Total coliform & & & & & & \\
\hline Final Effluent & 360 & 790 & $10^{5}$ & 1065 & 4000 & 980 \\
\hline E-coli & & & & & & \\
\hline Final Effluent & 18 & 700 & 83000 & 4 & 333 & 774 \\
\hline
\end{tabular}

\section{Conclusions}

The research work aimed at characterizing domestic wastewater samples obtained from six wastewater treatment plants in three regions in the sultanate of Oman (Muscat, Sohar and Salalah). The sampling process was carried out for 12 months (from January 2009 to December 2009). The analyses were conducted by running the main physical, chemical and microbiology tests. The conducted tests included $\mathrm{pH}$, electrical conductivity (EC), biochemical oxygen demand (BOD), chemical oxygen demand (COD), solids (TSS and TDS), anions, cations, ammonia and microbial content. It was found that most of the treatment plants applied secondary treatment systems (i.e. biological treatment in the form of activated sludge or aerated lagoons). The $\mathrm{pH}$ and $\mathrm{EC}$ of final effluents were found within regulated limits. Furthermore, the applied biological treatment was good in nutrient removal. The obtained values for $\mathrm{BOD}_{5}$ and $\mathrm{COD}$ were well within Omani Standards. However, the applied treatment systems were not effective in removal of heavy metals as the values of metals in the raw sewage are didn't vary much from the final effluents.

The obtained results indicated that there is a variation in the quality of the treated effluent from time to time (i.e. the final effluents quality parameters were found below the standard values in some visits and higher in other visits). At least two of the six treatment plants had high microbiological contamination in their final effluents. Thus, the disinfection systems in these plants need further investigation, improvements or redesign.

\section{References}

[1] Heidarpour, M., Mostafazadeh-Fard, B., Abedi Koupai, J., and Malekian, R., The effects of treated wastewater on soil chemical properties using subsurface and surface irrigation methods. Agricultural Water Management 90, pp. 87-94, 2007.

[2] Metcalf \& Eddy, Wastewater Engineering Treatment and Reuse. McGraw Hill, 4th ed, NY, 2003.

[3] Toze, S. Reuse of effluent water- benefits and risks. Agricultural Water Management, 80, pp 147-159, 2006. 
[4] National Research Council. Issues in Potable Reuse-The Viability of Augmenting Drinking Water Supplies with Reclaimed Water, National Academic Press, Washington, DC., 1998.

[5] Briand, J.F., Jacquet, S., Bernard, C. and Humbert, J.F. Health hazards for terrestrial vertebrates from toxic cyanobacteria in surface water ecosystems. Veterinary Research, 34(4), pp. 361-377, 2003.

[6] Carmichael, W.W., Toxins of cyanobacteria. Scientific American, 270(1), pp. 78-86, 1994.

[7] Pouria, S., de Andrade, A., Barbosa, J., Cavalcant i, R.L., Barreto, V.T.S., Ward, C.J., Preiser, W., Poon, G.K., Neild, G.H. and Codd, G.A. Fatal microcystin intoxication in haemodialysis unit in Caruaru, Brazil. Lancet 352, pp. 21-26, 1998.

[8] Sonnenschein, C., and Soto, A.M., An updated review of environmental estrogen and androgen mimics and antagonists. J. Steroid Biochem. Molec. Biol. 65(1-6), pp. 143-50, 1998.

[9] Lim, R., Gale, S., Doyle, C., Lesjean, B., and Gibert, M. Endocrine disrupting compounds in sewage treatment plant (STP) effluent reused in agriculture - is there a concern? In: Proceeding of the 1st Symposium Water Recycling, Australia, Adelaide, pp. 23-28, 2000.

[10] Lintelmann, J., Katayama, A., Kurihara, N., Shore, L., and Wenzel, A., Endocrine disrupting compounds in the environment. IUPAC technical report. Pure Appl. Chem., 75, pp. 631-681, 2003.

[11] Al-Sulaimani, Z.K. Water resources management in Sultanate of Oman. In: Proceedings of the International Workshop on Policies and Strategic Options for Water Management in the Islamic Countries, Iran, Tehran, pp. 1-9, 2003.

[12] Al-Futaisi, A., Rajmohan, N., and Al-Touqi, S. Integrated concept for groundwater evaluation and protection -Barka catchment (Oman) as case study. 8th Gulf Conference, pp. 1-10, 2007..

[13] Yaghi, B. 2007. Heavy metal levels in tap water in Batina Region, Oman. International Journal of Environment and Pollution, 31(1/2).

[14] Salalah Sanitary drainage Services Co., Monthly report No. 46, Month of May 2007. Prepared by O\&M Contractor: Oman National Engg. \& Investment Co. 2007. 